\title{
PENGARUH MIKROBA PELARUT FOSFAT DAN BATUAN FOSFAT TERHADAP PERTUMBUHAN DAN HASIL TANAMAN BAWANG MERAH (Allium ascalonicum L)
}

\section{EFFECT OF PHOSPHATE SOLUBILIZING MICROORGANISM AND ROCK PHOSPHATE FERTILIZER ON GROWTH AND YIELD OF SHALLOT ( Allium ascalonicum L)}

\author{
Deden $^{1)}$ dan Uum Umiyati²) \\ ${ }^{1)}$ Fakultas Pertanian Universitas Swadaya Gunung Jati \\ ${ }^{2}$ Fakultas Pertanian Universitas Padjadjaran \\ Email: deden@unswagati.ac.id
}

\begin{abstract}
Shallot (Allium ascalonicum L.) is one of the leading horticultural commodities that have been cultivated intensively by farmers, especially farmers in the Cirebon area. The purpose of this study was to determine the effect and interaction between the type of Phosphate Solubilizing Microbes and phosphate rock dosage on the growth and yield of shallot. The study was conducted in Playangan Village, Gebang District, Cirebon Regency, West Java. Research time is February to June 2019. The research method used is factorial randomized block design. The treatment consists of two factors. The first factor is $M 0=$ without Phosphate Solubilizing Microbes, M1 = Pseudomonas sp. and M2=MPF Penicillium sp. The second factor is the dose of phosphate rock which consists of three levels, namely $R 0=$ without phosphate rock, $R 1=$ dose of phosphate rock $50 \mathrm{~kg} / \mathrm{ha}, R 2=$ dose of phosphate rock $100 \mathrm{~kg} / \mathrm{ha}$ and $\mathrm{R} 3=$ dose of phosphate rock 150 $\mathrm{kg} / \mathrm{ha}$. The main observations observed include P uptake, plant height, number of leaves, biomass in each clump, number of tubers in each clump, fresh tuber weight in each plot, dry tuber diameter in each clump and each plot, dry tuber weight in each clump and each plot. The results showed an interaction between the treatment of phosphate solubilizing microbes and phosphate rock on P uptake, the number of leaves of 6 weeks after planting and the weight of dried tubers in each plot. In the P uptake, interaction occurred from M2R3 (Pseudomonas sp. + Dose of phosphate rock $100 \mathrm{~kg} / \mathrm{ha}$ ) showed P uptake $0.25 \%$ and M3R4 (Penicillium sp. + Dose of phosphate rock $100 \mathrm{~kg} / \mathrm{ha}$ ) showed absorption of P 0.21\%. The number of leaves 6 weeks after planting, M2R3 (Pseudomonas sp + phosphate rock dosage $100 \mathrm{~kg} / \mathrm{ha}$ ) showed 46.19 leaflets same as M2R4 (Pseudomonas sp + phosphate rock dosage $150 \mathrm{~kg} / \mathrm{ha}$ ). The dry tuber weights in each plot, on M2R3 (Pseudomonas sp. + $100 \mathrm{~kg}$ phosphate rock dosage / ha showed $5.75 \mathrm{~kg}$ in each plot or equivalent to 9.2 tons in each hectare. There was a significant correlation between plant height and number of leaves in 5 weeks after planting to the average dry tuber shallot.
\end{abstract}

Keywords: Phosphate solubilizing microbes, phosphate rock, shallot 


\begin{abstract}
ABSTRAK
Bawang merah (Allium ascalonicum L.) merupakan salah satu komoditas hortikultura unggulan yang sejak lama telah diusahakan oleh petani secara intensif, khusunya petani di wilayah Cirebon. Tujuan dari penelitian ini adalah untuk mengetahui pengaruh dan interaksi antara jenis Mikroba Pelarut Fospat (MPF) dan dosis batuan fosfat terhadap pertumbuhan dan hasil tanaman bawang merah. Penelitian dilaksanakan di Desa Playangan, Kecamatan Gebang, Kabupaten Cirebon, Jawa Barat. Waktu penelitian Februari sampai dengan Juni 2019. Metode penelitian yang digunakan yaitu Rancangan Acak Kelompok (RAK) faktorial. Perlakuan terdiri atas dua faktor. Faktor pertama yaitu M0 = Tanpa MPF, M1 = MPF Pseudomonas sp. dan M2= MPF Penicillium sp. Faktor kedua yaitu dosis batuan fosfat yang terdiri atas tiga taraf yaitu R0 = Tanpa Batuan fosfat, R1 = Takaran Batuan fosfat $50 \mathrm{~kg} / \mathrm{ha}, \mathrm{R} 2=$ Takaran Batuan fosfat $100 \mathrm{~kg} / \mathrm{ha}$ dan R3 = Takaran Batuan fosfat $150 \mathrm{~kg} /$ ha. Masing-masing perlakuan diulang tiga kali sehingga terdapat 36 satuan percobaan. Pengamatan utama yang diamati antara lain serapan $P$, tinggi tanaman, jumlah daun, biomassa per rumpun, jumlah umbi per rumpun, bobot umbi segar per petak, diameter umbi kering per rumpun dan per petak, bobot umbi kering per rumpun dan per petak. Hasil penelitian menunjukkan adanya interaksi antara perlakuan Mikroba Pelarut Fosfat dan batuan fosfat terhadap serapan P, jumlah daun 6 MST dan bobot umbi kering per petak, yaitu a). Pada serapan P, terjadi interaksi dari perlakuan $\mathrm{M}_{2} \mathrm{R}_{3}$ (MPF Pseudomonas sp. + takaran batuan fosfat $100 \mathrm{~kg} / \mathrm{ha}$ ) dengan serapan $\mathrm{P}$ mencapai $0,25 \%$ dan dari perlakuan $\mathrm{M}_{3} \mathrm{R}_{4}$ (MPF Penicillium sp. + takaran batuan fosfat $100 \mathrm{~kg} / \mathrm{ha}$ ) dengan serapan P 0,21\%, b). Pada jumlah daun umur $6 \mathrm{MST}$, terjadi interaksi antara perlakuan $\mathrm{M}_{2} \mathrm{R}_{3}(\mathrm{MPF}$ Pseudomonas sp + takaranbatuan fosfat $100 \mathrm{~kg} / \mathrm{ha}$ ) yang menghasilkan 46,19 helai daun dan interaksi antara perlakuan $\mathrm{M}_{2} \mathrm{R}_{4}$ (MPF Pseudomonas sp + takaran batuan fosfat $150 \mathrm{~kg} / \mathrm{ha}$ ) dengan hasil rata-rata jumlah daun sebanyak 44,03 helai serta interaksi antara perlakuan $\mathrm{M}_{3} \mathrm{R}_{3}$ (MPF Penicillium $s p+$ takaran batuan fosfat 100 $\mathrm{kg} / \mathrm{ha}$ ) yang menghasilkan rata-rata jumlah daun sebanyak 45,33 helai pada umur 6 MST. c) pada bobot umbi kering per petak, terjadi interaksi pada perlakuan $\mathrm{M}_{2} \mathrm{R}_{3}$ (MPF Pseudomonas sp. + takaran batuan fosfat 100 $\mathrm{kg} /$ ha yang menghasilkan bobot umbi kering $5,75 \mathrm{~kg}$ per petak atau setara dengan 9,2 ton/ha dengan asumsi luas efektif $80 \%$. Batuan fosfat memberikan pengaruh secara mandiri terhadap hasil rata-rata hasil tinggi tanaman 5 dan 6 MST, jumlah daun 5 MST, biomassa 5 dan 6 MST dan jumlah umbi per rumpun serta bobot umbi kering per rumpun. Mikroba Pelarut Fosfat memberikan pengaruh mandiri terhadap rata-rata hasil tinggi tanaman 5 dan $6 \mathrm{MST}$, bobot umbi segar dan bobot umbi kering per rumpun. 3). Terdapat hubungan korelasi yang nyata antara tinggi tanaman 5 dan 6 MST serta jumlah daun 5 MST terhadap rata-rata hasil bobot umbi kering per petak tanaman bawang merah.
\end{abstract}

Kata kunci : Bawang Merah, Batuan Fosfat, Mikroba Pelarut Fosfat

\section{PENDAHULUAN}

Umbi bawang merah (Allium ascalonicum L.) merupakan produk hortikultura yang dimanfaatkan pada berbagai masakan di Indonesia. Apabila terjadi kelangkaan produksi bawang merah maka harga mahal. Sebagai komoditas hortikultura yang banyak dikonsumsi masyarakat, potensi pengembangan

pertanaman bawang merah masih terbuka lebar, tidak saja untuk kebutuhan dalam negeri tetapi juga luar negeri (Suriani, 2012)

Berdasarkan Data Kementerian Pertanian (2019), pada tahun 2018 wilayah produksi bawang 
merah yang menempati urutan tiga besar adalah Jawa Tengah dengan produksi 445.586 ton, Jawa Timur 367.036 ton dan Nusa Tenggara Barat 212.885 ton. Data luas panen, produktivitas dan produksi bawang merah di Indonesia dalam kurun lima tahun terakhir tersaji pada Tabel 1 .

Lima tahun terakhir (tahun 2014-2018) produksi bawang merah mengalami peningkatan tiap tahun, namun rata-rata produktivitas bawang merah nasional masih rendah, sebagai contoh pada tahun 2018 produktivitasnya sekitar 9,59 ton/ha, jauh di bawah potensi produksi di atas 20 ton/ha. Rendahnya produksi bawang merah di Indonesia disebabkan oleh beberapa faktor, antara lain takaran pupuk yang tidak sesuai dengan anjuran, serta kemampuan tanaman dalam menyerap unsur hara dalam tanah.

Unsur fosfor $(\mathrm{P})$ adalah unsur esensial ke dua setelah nitrogen $(\mathrm{N})$ yang berperan penting dalam fotosintesis dan perkembangan akar (Ginting et al., 2006). Unsur P merupakan salah satu unsur penyusun cadangan energi dalam tanaman yaitu penyusun Adenosin Trifosfat(ATP) dalam tanaman. Menghadapi kendala-kendala dalam pemenuhan kebutuhan P pada tanaman terutama pada bawang merah yang membutuhkan banyak P untuk produksinya, maka perlu suatu usaha yang dapat menguraikan unsur $\mathrm{P}$ yang terikat dalam tanah dan mengefisienkan pemakaian pupuk $\mathrm{P}$ bagi tanaman. Salah satu alternatif yang dapat dilakukan adalah dengan memanfaatkan kelompok Mikroba Pelarut Fosfat yaitu mikroba yang dapat melarutkan P yang terikat oleh tanah dan pupuk P yang terakumulasi dalam tanah sehingga dapat diserap oleh tanaman. Pemanfaatan Mikroba Pelarut Fosfat diharapkan dapat mengatasi masalah $\mathrm{P}$ di tanah masam. Pupuk fosfor $(\mathrm{P})$ berpengaruh mempercepat pembungaan serta pematangan buah dan biji tanaman pada pemberian air $80 \%$ Kapasitas Lapang dengan pupuk $50 \mathrm{~kg}$ P2O5/ha pada tanaman bawang merah sehingga tinggi tanaman mencapai $44 \mathrm{~cm}$, jumlah daun 28,33 lembar/pot, diameter batang terbesar $0,627 \mathrm{~cm}$, permukaan daun terluas $665,3 \mathrm{~cm}^{2}$, bobot kering tanaman 52,70 g/pot, bobot umbi segar 14,90 g/pot, efisiensi penggunaan air mencapai $41 \%$, indek panen tertinggi 93, dan jumlah umbi terbanyak 10,67 siung/ pot.

Menurut Rosmarkam dan Yuwono (2002),

Tabel 1. Luas Panen, Produktivitas dan Produksi Bawang Merah di Indonesia

\begin{tabular}{cccc}
\hline \multirow{2}{*}{ Tahun } & \multicolumn{3}{c}{ Bawang Merah } \\
\cline { 2 - 4 } & Luas Panen $(\mathrm{Ha})$ & Produktivitas (Ton/Ha) & Produksi (Ton) \\
\hline 2014 & 120.704 & 10,22 & 1.233 .984 \\
2016 & 122.126 & 10,07 & 1.229 .184 \\
2016 & 149.635 & 9,67 & 1.446 .860 \\
2017 & 158.172 & 9,30 & 1.470 .155 \\
2018 & 156.779 & 9,59 & 1.503 .436 \\
\hline
\end{tabular}

Sumber: Kementerian Pertanian Republik Indonesia, 2019 
tanaman menyerap fosfor dalam bentuk ion ortofosfat primer (H2PO4) dan ion ortofosfat sekunder (HPO4-

$\left.{ }^{2}\right)$. Batuan fosfat merupakan fosfat yang berasal langsung dari alam yang diaplikasikan tanpa melalui pabrikasi. Fosfat alam adalah salah satu alternatif pupuk dengan tujuan menanggulangikekahatan $\mathrm{P}$ dalam tanah. Tepung fosfat alam dapat diaplikasikan secara langsung ke lahan tanpa melalui proses pabrik. Batuan fosfat atau tepung fosfat alam diaplikasikan ke lahan secara langsung dengan tujuan untuk menyediakan kebutuhan unsur fosfor $(\mathrm{P})$ bagi tanaman terutama pada tanah masam karena fosfor dalam batuan fosfat bersifat tidak mudah larut (Wahida dkk., 2007).

\section{BAHAN DAN METODE}

Penelitian dilaksanakan di Desa Playangan, Kecamatan Gebang, Kabupaten Cirebon, Jawa Barat. Lokasi penelitian merupakan wilayah binaan UPTD BP4K (Balai Penyuluhan Pertanian, Peternakan, dan Perkebunan) Kecamatan Gebang, Kabupaten Cirebon. Letak wilayah 3 meter di atas permukaan laut (mdpl) dan jenis tanah grumosol. Penelitian dilaksanakan Februari - Juni 2019. Bahan yang digunakan dalam penelitian ini adalah dua jenis Mikroba Pelarut Fosfat (MPF) yaitu Pseudomonas sp. dan Penicillium sp., batuan fosfat, pupuk Urea, $\mathrm{KCl}$ dan ZA. Organisme pengganggu tanaman dikendalikan dengan Insektisida dan Fungisida sesuai kebutuhan. Alat-alat yang digunakan dalam percobaan ini adalah cangkul, kored, sabit, tugal, meteran, penggaris, timbangan, papan nama, bambu/ajir, hand sprayer, alat tulis, dan alat perlengkapan laboratorium.
Metode percobaan yang digunakan yaitu menggunakan metode Rancangan Acak Kelompok (RAK) pola faktorial. Perlakuan terdiri dari dua faktor yaitu faktor pertama yaitu jenis Mikroba Pelarut Fosfat, sedangkan faktor ke dua adalah dosis batuan fosfat. Faktor pertama, penggunaan jenis Mikroba Pelarut Fosfat (M)yang terdiri atas 3 taraf, yaitu:

M0 : Tanpa Mikroba Pelarut Posfat (Kontrol)

M1 : Mikroba Pelarut Posfat Pseudomonas sp.

M2 : Mikroba Pelarut Posfat Penicillium sp.

Faktor ke dua yaitu dosis Batuan fosfat $(\mathrm{R})$ yang terdiri atas empat taraf, yaitu:

R0 = Tanpa Batuan fosfat (Kontrol)

$\mathrm{R} 1=$ Dosis Batuan fosfat $50 \mathrm{~kg} / \mathrm{ha}(30 \mathrm{~g} /$ petak $)$

$\mathrm{R} 2=$ Dosis Batuan fosfat $100 \mathrm{~kg} / \mathrm{ha}(60 \mathrm{~g} /$ petak $)$

R3 = Dosis Batuan fosfat $150 \mathrm{~kg} / \mathrm{ha}(90 \mathrm{~g} /$ petak$)$

Masing-masing kombinasi perlakuan diulang tiga kali sehingga terdapat 36 satuan percobaan.Data hasil pengamatan utama diolah menggunakan uji statistik model linier Toto Warsa dan Cucu S.A(1982) dalam Gaspersz (1989), dengan rumus :

$$
X i j k=i ̀+r i+M j+R k+(M R) j k+O ́ i j k .
$$

Uji hipotesis bagi efek perlakuan dilakukan dengan menggunakan uji F dan dilanjutkan dengan uji jarak berganda Duncan pada taraf $5 \%$.

\section{HASIL DAN PEMBAHASAN}

Pengamatan serapan P, tinggi tanaman, jumlah daun, biomassa per rumpun, jumlah umbi per rumpun, bobot umbi segar per petak, diameter umbi kering per rumpun dan per petak, bobot umbi kering per rumpun dan per petak. 


\section{Serapan $P(\%)$}

Terdapat interaksi antara perlakuan Mikroba Pelarut Fosfat dan batuan fosfat terhadap rata-rata serapan $\mathrm{P}$ tanaman bawang merah. Interaksi pertama yaitu antara perlakuan $\mathrm{M}_{2} \mathrm{R}_{3}$ (MPF Pseudomonas sp. + batuan fospat $100 \mathrm{~kg} / \mathrm{ha}$ ) dengan serapan P mencapai $0,25 \%$. Interaksi yang kedua adalah antara perlakuan $\mathrm{M}_{3} \mathrm{R}_{4}$ (MPF Penicillium sp. + batuan fospat $100 \mathrm{~kg} /$ ha) dengan 1 serapan P 0,21\% (Tabel 2).

Dari hasil tersebut dikatakan bahwa peran MPF jenis Pseudomonas sp lebih baik dibandingkan jenis Penicillium sp, karena Pseudomonas sp sudah mampu menghasilkan serapan yang tinggi hanya dengan aplikasi batuan fosfat $100 \mathrm{~kg} / \mathrm{ha}$, sementara Penicillium $s p$ terlihat interaksinya pada taraf aplikasi $150 \mathrm{~kg} / \mathrm{ha}$. Pemberian batuan fosfat yang bersumber dari batuan alam lebih efektif dan ekonomis (Sanchez, 1992). Santosa (2007) menyatakan, bahwa kemampuan
MPF tergantung dari jenis mikroba, daya adaptasi dan kemampuan dalam memproduksi asam-asam organik dan enzim fosfatase. Pseudomonas sp. merupakan bakteri yang mampu menghasilkan enzim fosfatase (fosfomonoesterase) yang termasuk dalam golongan enzim hidrolase.

\section{Tinggi Tanaman (cm)}

Berdasarkan hasil analisis dari perlakuan pengaruh Mikroba Pelarut Fosfat dan batuan fosfat tidak menunjukan adanya interaksi terhadap tinggi tanaman bawang merah yang diamati pada umur 4, 5, dan 6 MST, namun secara mandiri terdapat pengaruh dari masing-masing perlakuan. Secara mandiri batuan fosfat $100 \mathrm{~kg} /$ hektar $\left(\mathrm{R}_{3}\right)$ berpengaruh terhadap ratarata tinggi tanaman pada umur 5 dan 6 MST, sedangkan pada pengamatan 4 MST semua taraf batuan fosfat tidak berbeda nyata. Pada pengamatan 5 MST perlakuan $\mathrm{R}_{3}$ menghasilkan rata-rata tinggi

Tabel 2. Interaksi Pengaruh Mikroba Pelarut Fosfat dan Batuan Fosfat Terhadap Rata-rata Serapan P Tanaman Bawang Merah per Rumpun (\%)

\begin{tabular}{ccccc}
\hline Perlakuan & $\mathrm{R}_{1}$ & $\mathrm{R}_{2}$ & $\mathrm{R}_{3}$ & $\mathrm{R}_{4}$ \\
\hline & $0,15 \mathrm{a}$ & $0,15 \mathrm{a}$ & $0,16 \mathrm{a}$ & $0,16 \mathrm{a}$ \\
$\mathrm{M}_{1}$ & $\mathrm{~A}$ & $\mathrm{~A}$ & $\mathrm{~A}$ & $\mathrm{~A}$ \\
& $0,14 \mathrm{a}$ & $0,16 \mathrm{a}$ & $0,25 \mathrm{~b}$ & $0,19 \mathrm{a}$ \\
$\mathrm{M}_{2}$ & $\mathrm{~A}$ & $\mathrm{~A}$ & $\mathrm{C}$ & $\mathrm{B}$ \\
& $0,17 \mathrm{a}$ & $0,15 \mathrm{a}$ & $0,17 \mathrm{a}$ & $0,21 \mathrm{~b}$ \\
$\mathrm{M}_{3}$ & $\mathrm{~A}$ & $\mathrm{~A}$ & $\mathrm{~A}$ & $\mathrm{~B}$ \\
\hline
\end{tabular}

Keterangan : Angka rata-rata yang diikuti huruf yang sama pada kolom atau baris tidak berbeda nyata menurut Uji Jarak Berganda Duncan pada taraf 5\%.; M0 : Tanpa Mikroba Pelarut Posfat (Kontrol); M1 : Mikroba Pelarut Posfat Pseudomonas sp.; M2 : Mikroba Pelarut Posfat Penicillium sp.;R0= Tanpa Batuan fosfat (Kontrol); R1 = Dosis Batuan fosfat $50 \mathrm{~kg} / \mathrm{ha}$ (setara $30 \mathrm{~g} / \mathrm{petak}$ ); $\mathrm{R} 2$ = Dosis Batuan fosfat $100 \mathrm{~kg} / \mathrm{ha}$ (setara $60 \mathrm{~g} /$ petak);R3 = Dosis Batuan fosfat $150 \mathrm{~kg} / \mathrm{ha}$ (setara $90 \mathrm{~g} /$ petak) 
tanaman 36,12 $\mathrm{cm}$ dan pada pengamatan $6 \mathrm{MST}$ menghasilkan rata-rata tinggi tanaman $41,19 \mathrm{~cm}$ yang berbeda dari perlakuan taraf batuan fosfat lainya. Pada tanah agak masam media dalam penelitian ini, unsur hara yang dibutuhkan tanaman berada dalam bentuk ikatan kimia yang tidak dapat diserap langsung oleh tanaman sehingga dapat menyebabkan tanaman kekurangan fosfor (P). Kekurangan P pada tanaman tidak dapat secara mudah dipenuhi dengan pemberian pupuk $\mathrm{P}$, karena pupuk $\mathrm{P}$ yang diberikan tidak semua dapat diserap sepenuhnya oleh tanaman. Menurut Jones (1982) dari pupuk P yang diberikan hanya 10-30\% yang dapat diserap tanaman, selebihnya 70-90\% tetap berada atau terakumulasi di dalam tanah (Elfiati, 2005).

Pada perlakuan MPF secara mandiri juga menunjukan adanya pengaruh nyata. Perlakuan MPF Pseudomonas sp. $\left(\mathrm{M}_{2}\right)$ secara mandiri berpengaruh terhadap rata-rata tinggi tanaman pada umur pengamatan 5 MST dengan tinggi 35,64 cm dan 6 MST dengan tinggi 39,95 cm, sedangkan perlakuan
MPF Penicillium sp (M3) secara mandiri berpengaruh pada umur 6 MST dengan tinggi 37,86 cm. Hal ini diduga, enzim fosfatase yang dihasilkan mikroorganisme tanah dapat menghidrolisis senyawa fosfor organik menjadi senyawa fosfor anorganik. Hasil dari hidrolisis digunakan untuk memenuhi kebutuhan $\mathrm{P}$ anorganik untuk mikroorganisme tersebut dan dapat mengkontribusikan $\mathrm{P}$ anorganik ke dalam tanah yang dapat dimanfaatkan oleh tanaman (Richardson et al., 2001).

Pada Tabel 3 diatas, terlihat bahwa secara mandiri batuan fosfat $100 \mathrm{~kg} /$ hektar $\left(\mathrm{R}_{3}\right)$ berpengaruh terhadap rata-rata tinggi tanaman pada umur 5 dan 6 MST, sedangkan pada pengamatan 4 MST semua taraf batuan fosfat tidak berbeda nyata. Pada pengamatan 5 MST perlakuan $R_{3}$ rata-rata tinggi tanaman 36,12 $\mathrm{cm}$ dan pada pengamatan 6 MST rata-rata tinggi tanaman 41,19 cm yang berbeda dari perlakuan taraf batuan fosfat lainnya. Pada tanah agak masam media penelitian inimaka unsur hara yang dibutuhkan tanaman

Tabel 3. Pengaruh Mikroba Pelarut Fosfat dan Batuan Fosfat terhadap Rata-rata Tinggi Tanaman Bawang Merah Umur 4, 5 dan 6 MST (cm).

\begin{tabular}{|c|c|c|c|}
\hline \multirow{2}{*}{ Perlakuan } & \multicolumn{3}{|c|}{ Rata-rata Tinggi Tanaman (cm) } \\
\hline & $4 \mathrm{MST}$ & $5 \mathrm{MST}$ & $6 \mathrm{MST}$ \\
\hline \multicolumn{4}{|l|}{ Batuan Fospat (R) } \\
\hline $\mathrm{R}_{1}=$ Tanpa batuan fosfat & $26,17 \mathrm{a}$ & $34,01 \mathrm{a}$ & $37,17 \mathrm{a}$ \\
\hline $\mathrm{R}_{2}=$ Batuan fosfat $50 \mathrm{~kg} / \mathrm{ha}$ & $26,51 \mathrm{a}$ & $34,02 \mathrm{a}$ & $38,82 \mathrm{a}$ \\
\hline $\mathrm{R}_{3}=$ Batuan fosfat $100 \mathrm{~kg} / \mathrm{ha}$ & $27,31 \mathrm{a}$ & $36,12 \mathrm{~b}$ & $41,19 b$ \\
\hline $\mathrm{R}_{4}=$ Batuan fosfat $150 \mathrm{~kg} / \mathrm{ha}$ & 26,23 a & $33,13 \mathrm{a}$ & $37,29 \mathrm{a}$ \\
\hline \multicolumn{4}{|c|}{ Mikroba Pelarut Fosfat (M) } \\
\hline $\mathrm{M}_{1}=$ Tanpa MPF & $23,25 \mathrm{a}$ & $33,18 \mathrm{a}$ & $35,55 \mathrm{a}$ \\
\hline $\mathrm{M}_{2}=$ MPF Pseudomonas sp. & $24,48 \mathrm{a}$ & $35,64 \mathrm{~b}$ & $39,96 \mathrm{~b}$ \\
\hline $\mathrm{M}_{3}=$ MPF Penicillium $s p$ & $24,14 \mathrm{a}$ & $33,42 \mathrm{a}$ & $37,86 \mathrm{~b}$ \\
\hline
\end{tabular}

Keterangan : Angka rata-rata yang diikuti huruf yang sama tidak berbeda nyata menurut Uji Jarak Berganda Duncan 5\%. 
berada dalam bentuk ikatan kimia yang tidak dapat diserap langsung oleh tanaman sehingga dapat menyebabkan tanaman kekurangan fosfor $(\mathrm{P})$. Kekurangan P pada tanaman tidak dapat secara mudah dipenuhi dengan pemberian pupuk $\mathrm{P}$, karena pupuk $\mathrm{P}$ yang diberikan tidak semua dapat diserap sepenuhnya oleh tanaman. Menurut Jones (1982) dari pupuk P yang diberikan hanya 10-30\% yang dapat diserap tanaman, selebihnya $70-90 \%$ tetap berada atau terakumulasi di dalam tanah (Elfiati, 2005).

Pada perlakuan MPF secara mandiri juga menunjukan adanya pengaruh nyata. Perlakuan MPF Pseudomonas sp. $\left(\mathrm{M}_{2}\right)$ secara mandiri berpengaruh terhadap rata-rata tinggi tanaman pada umur pengamatan 5 dengan tinggi 35,64 $\mathrm{cm}$ dan $6 \mathrm{MST}$ dengan tinggi 39,95 cm, sedangkan perlakuan MPF Penicillium sp (M3) secara mandiri berpengaruh pada umur $6 \mathrm{MST}$ dengan tinggi 37,86 cm. Hal ini diduga, enzim fosfatase yang dihasilkan mikroorganisme tanah dapat menghidrolisis senyawa fosfor organik menjadi senyawa fosfor anorganik. Hasil dari hidrolisis digunakan untuk memenuhi kebutuhan $\mathrm{P}$ anorganik untuk mikroorganisme tersebut dan dapat mengkontribusikan P anorganik ke dalam tanah yang dapat dimanfaatkan oleh tanaman (Richardson et al., 2001)

\section{Jumlah Daun (helai)}

Pada pengamatan jumlah daun umur 4 dan 5 MST, perlakuan Mikroba Pelarut Fosfat dan batuan fosfat berpengaruh secara mandiri, namun pada pengamatan $6 \mathrm{MST}$ kedua faktor tersebut menunjukan adanya interaksi. Perlakuan batuan fosfat secara madiri berpengaruh nyata terhadap jumlah daun 5 MST, yaitu 37,16 helai pada perlakuan takaran batuan fosfat 50 $\mathrm{kg} / \mathrm{ha}, 38,60$ helai pada perlakuan takaran batuan fosfat $150 \mathrm{~kg} /$ ha dan yang terbanyak adalah perlakuan takaran batuan fosfat $100 \mathrm{~kg} /$ ha untuk jumlah daun 42,38 helai. Perlakuan Mikroba Pelarut Fosfat secara mandiri berpengaruh nyata, yaitu pada perlakuan MPF jenis Pseudomonas sp $\left(\mathrm{M}_{2}\right)$ yang menghasilkan rata-rata

Tabel 4. Pengaruh Mikroba Pelarut Fosfat dan Batuan Fosfat terhadap Jumlah Rata-rata Daun Tanaman Bawang Merah per Rumpun Umur 4, dan 5 MST (helai)

\begin{tabular}{lcc}
\hline \multicolumn{1}{c}{ Perlakuan } & \multicolumn{2}{c}{ Rata-rata Jumlah Daun (helai) } \\
\cline { 2 - 3 }$\quad$ Batuan Fospat (R) & $4 \mathrm{MST}$ & $5 \mathrm{MST}$ \\
\hline $\mathrm{R}_{1}=$ Tanpa batuan fosfat & & \\
$\mathrm{R}_{2}=$ Batuan fosfat $50 \mathrm{~kg} / \mathrm{ha}$ & $25,20 \mathrm{a}$ & $35,02 \mathrm{a}$ \\
$\mathrm{R}_{3}=$ Batuan fosfat $100 \mathrm{~kg} / \mathrm{ha}$ & $25,16 \mathrm{a}$ & $37,16 \mathrm{~b}$ \\
$\mathrm{R}_{4}=$ Batuan fosfat $150 \mathrm{~kg} / \mathrm{ha}$ & $26,13 \mathrm{a}$ & $42,38 \mathrm{c}$ \\
$\quad$ Mikroba Pelarut Fosfat (M) & $27,92 \mathrm{a}$ & $38,60 \mathrm{~b}$ \\
$\mathrm{M}_{1}=$ Tanpa MPF & & \\
$\mathrm{M}_{2}=$ MPF Pseudomonas sp. & $23,45 \mathrm{a}$ & $38,01 \mathrm{a}$ \\
$\mathrm{M}_{3}=$ MPF Penicillium sp. & $29,70 \mathrm{~b}$ & $40,62 \mathrm{~b}$ \\
\hline
\end{tabular}

Keterangan : Angka rata-rata yang diikuti huruf yang sama tidak berbeda nyata menurut Uji Jarak Berganda Duncan 5\%. 
jumlah daun 29,70 helai pada umur 4 MST dan 40,62 helai pada umur 5 MST (Tabel 4).

Pada Tabel 5 di atas terlihat bahwa terjadi interaksi antara perlakuan Mikroba Pelarut Fosfat dan batuan fosfat terhadap rata-rata jumlah daun pada umur pengamatan $6 \mathrm{MST}$. Interaksi terlihat pada perlakuan $\mathrm{M}_{2} \mathrm{R}_{3}$ (MPF Pseudomonas sp + batuan fosfat 100 $\mathrm{kg} / \mathrm{ha}$ ) yang menghasilkan 46,19 helai daun. Interaksi lain yaitu perlakuan $\mathrm{M}_{2} \mathrm{R}_{4}$ (MPF Pseudomonas sp + batuan fosfat $150 \mathrm{~kg} / \mathrm{ha}$ ) dengan hasil rata-rata jumlah daun sebanyak 44,03 helai. Interaksi yang ketiga yaitu pada perlakuan $\mathrm{M}_{3} \mathrm{R}_{3}(\mathrm{MPF}$ Penicillium $s p+$ batuan fosfat $100 \mathrm{~kg} / \mathrm{ha}$ ) yang menghasilkan rata-rata jumlah daun sebanyak 45,33 helai.

\section{Biomassa per Rumpun (g)}

Hasil analisis statistik dari perlakuan Mikroba Pelarut Fosfat dan batuan fosfat terhadap pengamatan biomassa tanaman tidak menunjukan adanya interaksi, namun terdapat efek mandiri perlakuan tersebut.

Tabel 5. Interaksi Pengaruh Mikroba Pelarut Fosfat dan Batuan Fosfat terhadap Jumlah Rata-rata Jumlah Daun Tanaman Bawang Merah per Rumpun Umur 6 MST (helai)

\begin{tabular}{ccccc}
\hline Perlakuan & $\mathrm{R}_{1}$ & $\mathrm{R}_{2}$ & $\mathrm{R}_{3}$ & $\mathrm{R}_{4}$ \\
\hline $\mathrm{M}_{1}$ & $38,06 \mathrm{a}$ & $39,36 \mathrm{a}$ & $42,73 \mathrm{a}$ & $41,51 \mathrm{a}$ \\
& $\mathrm{A}$ & $\mathrm{A}$ & $\mathrm{A}$ & $\mathrm{A}$ \\
$\mathrm{M}_{2}$ & $39,87 \mathrm{a}$ & $40,07 \mathrm{a}$ & $46,19 \mathrm{~b}$ & $44,03 \mathrm{~b}$ \\
& $\mathrm{~A}$ & $\mathrm{~A}$ & $\mathrm{C}$ & $\mathrm{B}$ \\
$\mathrm{M}_{3}$ & $40,96 \mathrm{a}$ & $42,05 \mathrm{~b}$ & $45,33 \mathrm{~b}$ & $42,70 \mathrm{a}$ \\
& $\mathrm{A}$ & $\mathrm{A}$ & $\mathrm{B}$ & $\mathrm{A}$ \\
\hline
\end{tabular}

Keterangan : Angka rata-rata yang diikuti huruf yang sama pada kolom atau baris tidak berbeda nyata menurut Uji Jarak Berganda Duncan pada taraf 5\%. $\mathrm{R}=$ Batuan Fosfat, $\mathrm{M}=$ Mikroba Pelarut Fosfat.

Tabel 6. Pengaruh Mikroba Pelarut Fosfat dan Batuan Fosfat terhadap Rata-rata Biomassa Tanaman Bawang Merah per Rumpun (g)

\begin{tabular}{|c|c|c|c|}
\hline \multirow{2}{*}{ Perlakuan } & \multicolumn{3}{|c|}{ Biomassa Tanaman $(\mathrm{g})$} \\
\hline & $4 \mathrm{MST}$ & $5 \mathrm{MST}$ & $6 \mathrm{MST}$ \\
\hline \multicolumn{4}{|l|}{ Batuan Fospat (R) } \\
\hline $\mathrm{R}_{1}=$ Tanpa batuan fosfat & $2,42 \mathrm{a}$ & 5,18 a & $7,35 \mathrm{a}$ \\
\hline $\mathrm{R}_{2}=$ Batuan fosfat $50 \mathrm{~kg} / \mathrm{ha}$ & $2,86 \mathrm{a}$ & $5,60 \mathrm{a}$ & $7,79 \mathrm{a}$ \\
\hline $\mathrm{R}_{3}=$ Batuan fosfat $100 \mathrm{~kg} / \mathrm{ha}$ & $2,79 \mathrm{a}$ & $6,51 \mathrm{~b}$ & $9,33 \mathrm{c}$ \\
\hline $\begin{array}{l}\mathrm{R}_{4}=\text { Batuan fosfat } 150 \mathrm{~kg} / \mathrm{ha} \\
\text { Mikroba Pelarut Fosfat }(\mathrm{M})\end{array}$ & $2,95 \mathrm{a}$ & $6,12 b$ & $8,29 \mathrm{~b}$ \\
\hline $\mathrm{M}_{1}=$ Tanpa MPF & $2,75 \mathrm{a}$ & 5,87 a & $7,85 \mathrm{a}$ \\
\hline $\mathrm{M}_{2}=\mathrm{MPF}$ Pseudomonas sp. & 2,93 a & $6,17 \mathrm{a}$ & $8,42 \mathrm{a}$ \\
\hline $\mathrm{M}_{3}=\mathrm{MPF}$ Penicillium $s p$ & $2,60 \mathrm{a}$ & $5,52 \mathrm{a}$ & $8,29 \mathrm{a}$ \\
\hline
\end{tabular}

Keterangan : Angka rata-rata yang diikuti huruf yang sama tidak berbeda nyata menurut Uji Jarak Berganda Duncan 5\%. 
Pada Tabel 6 terlihat bahwa perlakuan Mikroba Pelarut Fosfat dan takaran batuan fosfat tidak menunjukkan perbedaan yang nyata terhadap biomassa tanaman pada umur 4 dan 5 MST. Namun pada pengamatan $6 \mathrm{MST}$, perlakuan batuan fosfat secara mandiri menunjukan perbedaan yang nyata dibandingan dengan perlakuan lainya, yaitu pada perlakuan batuan fosfat $100 \mathrm{~kg} /$ ha menghasilkan 9,33 $\mathrm{g}$ dan perlakuan batuan fosfat $150 \mathrm{~kg} / \mathrm{ha}$ menghasilkan $8,29 \mathrm{~g}$.

\section{Jumlah Umbi per Rumpun (siung)}

Hasil analisis statistik dari pengaruh Mikroba Pelarut Fosfat dan batuan fosfat terhadap rata-rata jumlah umbi tanaman bawang merah per rumpun tidak menunjukan adanya pengaruh interaksi. Namun secara mandiri batuan fosfat memberikan adanya perbedaan yang nyata yaitu pada perlakuan $\left(\mathrm{R}_{4}\right)$ batuan fosfat 150 $\mathrm{kg} / \mathrm{ha}$ berbeda dengan taraf perlakuan batuan fosfat lainya yaitu menghasilkan rata-rata 9,88 siung per rumpun. Perlakuan Mikroba Pelarut Fosfat secara mandiri tidak memberikan pengaruh terhadap rata-rata hasil jumlah umbi per rumpun. Sri Handayani (2001) menyatakan tanaman bawang merah akan aktif membelah membentuk anakan setelah fase pertumbuhan vegetatif yang dicapai. Suwandi \& Rosliani (2004), Asandhi et al. (2005), Gunadi (2009), Napitupulu \& Winarto (2010) menyatakan bahwa pemberian pupuk organik ataupun pupuk N, P, dan K tidak berpengaruh terhadap jumlah anakan tanaman bawang merah. Tampaknya jumlah anakan lebih banyak ditentukan oleh faktor genetik daripada ditentukan oleh faktor pemupukan.

\section{Diameter Umbi Kering per Petak (cm)}

Hasil analisis jumlah umbi per rumpun secara rinci dapat dilihat pada Tabel 8.

Tabel 8 menunjukkan tidak adanya interaksi antara Mikroba Pelarut Fosfat dan batuan fosfat dan secara mandiri semua perlakuan tidak menunjukan perbedaan yang nyata terhadap rata-rata diameter umbi per petak. Diameter umbi hanya dipengaruhi oleh sifat genetik umbi yang digunakan.

Tabel 7. Pengaruh Mikroba Pelarut Fosfat dan Batuan Fosfat terhadap Rata-rata Jumlah Umbi per Rumpun Tanaman Bawang Merah (siung)

\begin{tabular}{lc}
\hline \multicolumn{1}{c}{ Perlakuan } & Jumlah Umbi per Rumpun (siung) \\
\hline \multicolumn{1}{c}{ Batuan Fospat (R) } \\
$\mathrm{R}_{1}=$ Tanpa batuan fosfat & $7,58 \mathrm{a}$ \\
$\mathrm{R}_{2}=$ Batuan fosfat $50 \mathrm{~kg} / \mathrm{ha}$ & $7,66 \mathrm{a}$ \\
$\mathrm{R}_{3}=$ Batuan fosfat $100 \mathrm{~kg} / \mathrm{ha} 0$ & $7,79 \mathrm{a}$ \\
$\mathrm{R}_{4}=$ Batuan fosfat $150 \mathrm{~kg} / \mathrm{ha}$ & $9,88 \mathrm{~b}$ \\
$\quad$ Mikroba Pelarut Fosfat (M) & \\
$\mathrm{M}_{1}=$ Tanpa MPF & $7,38 \mathrm{a}$ \\
$\mathrm{M}_{2}=$ MPF Pseudomonas $s p$. & $7,22 \mathrm{a}$ \\
$\mathrm{M}_{3}=$ MPF Penicillium sp. & $6,58 \mathrm{a}$ \\
\hline
\end{tabular}

Keterangan : Angka rata-rata yang diikuti huruf yang sama tidak berbeda nyata menurut Uji Jarak Berganda Duncan 5\%. 


\section{Bobot Umbi Segar dan Bobot Umbi kering per Rumpun (g)}

Tabel 9 di bawah ini menunjukan bahwa tidak ada interaksi antara perlakuan Mikroba Pelarut Fosfat dan batuan fosfat terhadap hasil rata-rata bobot umbi segar dan bobot umbi kering per rumpun, namun terdapat pengaruh secara mandiri dari masing-masing faktor tersebut.

Perlakuan batuan fosfat tidak menunjukan perbedaan yang nyata terhadap hasil rata-rata bobot umbi segar bawang merah. Perlakuan batuan fosfat $100 \mathrm{~kg} / \mathrm{ha}\left(\mathrm{R}_{3}\right)$ dan batuan fosfat $150 \mathrm{~kg} / \mathrm{ha}\left(\mathrm{R}_{4}\right)$ menunjukan perbedaan yang nyata terhadap terhadap hasil rata-rata bobot umbi kering bawang merah jika dibandingkan perlakuan batuan fosfat yang hanya 50 $\mathrm{kg} /$ ha dan kontrol. Perlakuan MPF Pseudomonas sp. berbeda nyata jika dibandingkan dengan perlakuan MPF lainnya.

\section{Bobot Umbi Kering per Petak (kg).}

Hasil penelitian menunjukan bahwa terdapat interaksi Mikroba Pelarut Fosfat dan batuan fosfat terhadap hasil rata-rata bobot umbi kering bawang merah per petak (Tabel 12). Interaksi terjadi pada

Tabel 8. Pengaruh Mikroba Pelarut Fosfat dan Batuan Fosfat terhadap Rata-rata Diameter Umbi Bawang Merah $(\mathrm{cm})$

\begin{tabular}{lc}
\hline \multicolumn{1}{c}{ Perlakuan } & Diameter Umbi $(\mathrm{cm})$ \\
\hline $\mathrm{R}_{1}=$ Tanpa batuan fosfat & $2,53 \mathrm{a}$ \\
$\mathrm{R}_{2}=$ Batuan fosfat $50 \mathrm{~kg} / \mathrm{ha}$ & $2,63 \mathrm{a}$ \\
$\mathrm{R}_{3}=$ Batuan fosfat $100 \mathrm{~kg} / \mathrm{ha}$ & $2,68 \mathrm{a}$ \\
$\mathrm{R}_{4}=$ Batuan fosfat $150 \mathrm{~kg} / \mathrm{ha}$ & $2,67 \mathrm{a}$ \\
$\quad$ Mikroba Pelarut Fosfat $(\mathrm{M})$ & \\
$\mathrm{M}_{1}=$ Tanpa MPF & $2,28 \mathrm{a}$ \\
$\mathrm{M}_{2}=$ MPF Pseudomonas sp. & $2,35 \mathrm{a}$ \\
$\mathrm{M}_{3}=$ MPF Penicillium sp. & $2,26 \mathrm{a}$ \\
\hline
\end{tabular}

Keterangan : Angka rata-rata yang diikuti huruf yang sama tidak berbeda nyata menurut Uji Jarak Berganda Duncan 5\%.

Tabel 9. Pengaruh Mikroba Pelarut Fosfat dan Batuan Fosfat terhadap Rata-rata Bobot Umbi Segar dan Bobot Umbi kering Bawang Merah per Rumpun (g)

\begin{tabular}{lrr}
\hline \multicolumn{1}{c}{ Perlakuan } & \multicolumn{2}{c}{ Rata-rata Bobot Umbi per Rumpun $(\mathrm{g})$} \\
\cline { 2 - 3 } \multicolumn{1}{c}{ Dosis Pupuk (N) } & \multicolumn{1}{c}{ Kegar } \\
$\mathrm{R}_{1}=$ Tanpa batuan fosfat & $121,38 \mathrm{a}$ \\
$\mathrm{R}_{2}=$ Batuan fosfat $50 \mathrm{~kg} / \mathrm{ha}$ & $123,73 \mathrm{a}$ & $97,91 \mathrm{a}$ \\
$\mathrm{R}_{3}=$ Batuan fosfat $100 \mathrm{~kg} / \mathrm{ha}$ & $131,43 \mathrm{a}$ & $101,94 \mathrm{a}$ \\
$\mathrm{R}_{4}=$ Batuan fosfat $150 \mathrm{~kg} / \mathrm{ha}$ & $126,66 \mathrm{a}$ & $108,84 \mathrm{~b}$ \\
$\quad$ Mikroba Pelarut Fosfat (M) & & $105,96 \mathrm{~b}$ \\
$\mathrm{M}_{1}=$ Tanpa MPF & $118,94 \mathrm{a}$ & \\
$\mathrm{M}_{2}=$ MPF Pseudomonas sp & $132,94 \mathrm{c}$ & $97,32 \mathrm{a}$ \\
$\mathrm{M}_{3}=$ MPF Penicillium sp. & $126,27 \mathrm{~b}$ & $107,29 \mathrm{~b}$ \\
\hline $\mathrm{K}$ & & $107,19 \mathrm{~b}$ \\
\hline
\end{tabular}

Keterangan : Angka rata-rata yang diikuti huruf yang sama tidak berbeda nyata menurut Uji Jarak Berganda Duncan 5\%. 
Tabel 10. Pengaruh Mikroba Pelarut Fosfat dan Batuan Fosfat Terhadap Rata-rata Bobot Umbi Kering Bawang Merah per Petak $(\mathrm{Kg})$

\begin{tabular}{ccccc}
\hline Perlakuan & $\mathrm{R}_{1}$ & $\mathrm{R}_{2}$ & $\mathrm{R}_{3}$ & $\mathrm{R}_{4}$ \\
\hline $\mathrm{M}_{1}$ & $4,08 \mathrm{a}$ & $3,96 \mathrm{a}$ & $4,02 \mathrm{~b}$ & $3,89 \mathrm{a}$ \\
& $\mathrm{A}$ & $\mathrm{A}$ & & $\mathrm{A}$ \\
$\mathrm{M}_{2}$ & $4,29 \mathrm{a}$ & $4,36 \mathrm{a}$ & $5,74 \mathrm{~b}$ & $4,58 \mathrm{a}$ \\
& $\mathrm{A}$ & $\mathrm{A}$ & $\mathrm{C}$ & $\mathrm{B}$ \\
$\mathrm{M}_{3}$ & $4,26 \mathrm{a}$ & $4,59 \mathrm{a}$ & $4,19 \mathrm{a}$ & $4,59 \mathrm{a}$ \\
\hline
\end{tabular}

Keterangan : Angka rata-rata yang diikuti huruf yang sama pada kolom atau baris tidak berbeda nyata menurut Uji Jarak Berganda Duncan pada taraf 5\%.

Tabel 11. Hasil Analisis Korelasi Tinggi Tanaman dengan Bobot Umbi Kering per Petak

\begin{tabular}{|c|c|c|c|}
\hline \multirow{2}{*}{ Uraian } & \multicolumn{3}{|c|}{ Tinggi Tanaman } \\
\hline & $4 \mathrm{MST}$ & $5 \mathrm{MST}$ & $6 \mathrm{MST}$ \\
\hline Nilai $\mathrm{r}$ & 0,265 & 0,397 & 0,388 \\
\hline Kategori r & Korelasi rendah & Korelasi rendah & Korelasi rendah \\
\hline Nilai $r^{2}$ & 0,088 & 0,156 & 0,134 \\
\hline Nilai t & 1,745 & 2,470 & 2,388 \\
\hline Nilai $_{0,025}$ & 2,060 & 2,060 & 2,060 \\
\hline Kesimpulan & Tidak Nyata & Nyata & Nyata \\
\hline
\end{tabular}

perlakuan $\left(\mathrm{M}_{2}\right)$ MPF Pseudomonas sp. dengan $\left(\mathrm{R}_{3}\right)$ Batuan fosfat $100 \mathrm{~kg} / \mathrm{ha}$ yang hasilnya berbeda nyata dengan perlakuan lainya yaitu dengan bobot $5,75 \mathrm{~kg}$ per petak atau setara dengan 9,2 ton/ha dengan asumsi luas efektif sekitar $80 \%$.

Berdasarkan analisis hasil perhitungan uji Korelasi Moment Product Pearson maka korelasi antara komponen pertumbuhan dan hasil tanaman bawang merah (Allium ascalonicum L.) karena pengaruh Mikroba Pelarut Fosfat dan batuan fosfat dapat dilihat pada Tabel 11, 12 dan 13

Pada Tabel 11 terlihat bahwa tinggi tanaman 4 MST tidak berkorelasi dengan hasil bobot umbi kering tanaman bawang, karena setelah dilakukan uji t diperolah bahwa $\mathrm{t}_{\text {hitung }}<\mathrm{t}_{\text {tabel, }}$, namun pada pengamatan 5 MST dan 6 MST tinggi tanaman mempunyai hubungan korelasi terhadap hasil bobot umbi kering tanaman bawang, karena setelah dilakukan uji t diperoleh bahwa $t_{\text {hitung }}>t_{\text {tabel }}$. Berdasarkan hasil perhitungan koefisiensi Determinasi $\left(\mathrm{r}^{2}\right)$ secara berturutturut : $0,088,0,156$ dan 0,134 , artinya bahwa hasil bawang merah per petak dipengaruhi oleh tinggi tanaman pada umur 4 MST sebesar 8,8 \%, 5 MST sebesar 15,6\%, dan 6 MST sebesar 13,4\%. Adapun kategori korelasi tinggi tanaman umur 4 MST, 5 MST, $6 \mathrm{MST}$ adalah rendah.

Berdasarkan hasil analisis, pada pengamatan 4 MST dan 6 MST tidak menunjukan korelasi yang 
Tabel 12. Hasil Analisis Korelasi Jumlah Daun dengan Bobot Umbi Kering per Petak

\begin{tabular}{|c|c|c|c|}
\hline \multirow{2}{*}{ Uraian } & \multicolumn{3}{|c|}{ Jumlah Daun } \\
\hline & $4 \mathrm{MST}$ & $5 \mathrm{MST}$ & $6 \mathrm{MST}$ \\
\hline Nilai $r$ & 0,184 & 0,475 & 0,284 \\
\hline Kategori r & Korelasi sangat rendah & Korelasi sedang & Korelasi rendah \\
\hline$N$ ilai $r^{2}$ & 0,050 & 0,187 & 0,098 \\
\hline Nilai t & 1,043 & 2,935 & 1,610 \\
\hline$N$ ilai $t_{0,025}$ & 2,060 & 2,060 & 2,060 \\
\hline Kesimpulan & Tidak Nyata & Nyata & Tidak Nyata \\
\hline
\end{tabular}

Tabel 13. Hasil Analisis Korelasi Biomasaa Tanaman dengan Bobot Umbi Kering per Petak

\begin{tabular}{|c|c|c|c|}
\hline \multirow[b]{2}{*}{ Uraian } & \multicolumn{3}{|c|}{ Biomassa } \\
\hline & $4 \mathrm{MST}$ & $5 \mathrm{MST}$ & $6 \mathrm{MST}$ \\
\hline Nilai r & 0,062 & $-0,039$ & 0,162 \\
\hline Kategori r & Korelasi sangat rendah & Tidak berkorelasi & Korelasi sangat rendah \\
\hline Nilai $r^{2}$ & 0,004 & 0,002 & 0,031 \\
\hline Nilai t & 0,512 & $-0,354$ & 1,016 \\
\hline Nilai $t_{0,025}$ & 2,060 & 2,060 & 2,060 \\
\hline Kesimpulan & Tidak Nyata & Tidak Nyata & Tidak Nyata \\
\hline
\end{tabular}

nyata antara jumlah daun dengan bobot umbi kering per petak, karena setelah dilakukan uji t diperoleh bahwa $\mathrm{t}_{\text {hitung }}<\mathrm{t}_{\text {tabel. }}$ Pada pengamatan 5 MST, jumlah daun dengan bobot biji kering per petak menunjukan hubungan korelasi yang nyata dengan kategori korelasi sedang, karena setelah dilakukan uji t diperoleh bahwa $t_{\text {hitung }}>t_{\text {tabel. }}$ Kategori korelasi pada jumlah daun 4 MST yaitu sangat rendah dan jumlah daun 6 MST dengan kategori rendah. Berdasarkan hasil perhitungan koefisiensi Determinasi $\left(\mathrm{r}^{2}\right)$ secara berturut-turut : 0,050 0,187, 0,098, artinya bahwa hasil bawang merah per petak dipengaruhi jumah daun 4 MST sebesar 0,5\%, umur 5 MST sebesar 18,7 \%, dan 6 MST sebesar $0,9 \%$.

Berdasarkan hasil analisis, biomassa tanaman dengan bobot umbi kering per petak pada semua umur pengamatan (4 MST, 5 MST dan 6 MST) tidak menunjukan adanya hubungan korelasi yang nyata, karena setelah dilakukan uji t diperolah bahwa semua $t_{\text {hitung }}>t_{\text {tabel, }}$, dengan kategori korelasi sangat rendah pada umur 4 dan 6 MST, dan tidak berkorelasi pada unur 5 MST,Berdasarkan hasil perhitungan koefisiensi Determinasi $\left(\mathrm{r}^{2}\right)$ secara berturut-turut : $0,004,0,002$, 0,031 artinya bahwa hasil bobot umbi kering bawang merah per petak hanya dipengaruhi oleh jumlah daun umur 4 MST sebesar 0,04\%, umur 5 MST sebesar $0,02 \%$, dan umur 6 MST sebesar $0,31 \%$.

\section{KESIMPULAN}

Pengaruh Mikroba Pelarut Fosfat dan batuan fosfat terhadap pertumbuhan dan hasil tanaman bawang merah (Aliium ascalonicum) disimpulkan sebagai berikut : 
1. Terdapat interaksi antara perlakuan Mikroba Pelarut Fosfat dan batuan fosfat terhadap serapan $\mathrm{P}$, jumlah daun 6 MST dan bobot umbi per petak, yaitu :

a. Pada serapan P, terjadi interaksi dari perlakuan $\mathrm{M}_{2} \mathrm{R}_{3}$ (MPF Pseudomonas sp. + batuan fospat 100 $\mathrm{kg} / \mathrm{ha}$ ) dengan serapan P mencapai 0,25\% dan dari perlakuan $\mathrm{M}_{3} \mathrm{R}_{4}(\mathrm{MPF}$ Penicillium sp. + batuan fospat $100 \mathrm{~kg} / \mathrm{ha}$ ) dengan serapan $0,21 \%$.

b. Pada jumlah daun umur $6 \mathrm{MST}$, terjadi 3 interaksi dari kedua faktor perlakuan. Pertama, $\mathrm{M}_{2}(\mathrm{MPF}$ Pseudomonas sp) dan $\mathrm{R}_{3}$ (batuan fosfat $100 \mathrm{~kg} / \mathrm{ha}$ ) menghasilkan jumlah daun 46,19 helai daun. Kedua, $\mathrm{M}_{2}$ (MPF Pseudomonas $s p$ ) dan $\mathrm{R}_{4}$ (batuan fosfat $150 \mathrm{~kg} / \mathrm{ha}$ ) menghasilkan jumlah daun 44,03 helai. Ketiga, $\left(\mathrm{M}_{3}\right)$ MPF Penicillium $s p$ dan $\mathrm{R}_{3}$ (batuan fosfat $100 \mathrm{~kg} / \mathrm{ha}$ ) menghasilkan rata-rata jumlah daun 45,33 helai.

c. Pada bobot umbi kering per petak, terjadi interaksi pada perlakuan $\left(\mathrm{M}_{2}\right)$ MPF Pseudomonas sp. dengan $\left(\mathrm{R}_{3}\right)$ Batuan fosfat $100 \mathrm{~kg} /$ ha berbeda nyata dengan perlakuan lainya yaitu bobot umbi kering mencapai $5,75 \mathrm{~kg}$ per petak atau setara dengan 9,2 ton/ha dengan asumsi luas efektif sekitar $80 \%$.

2. Batuan fosfat memberikan pengaruh secara mandiri terhadap hasil rata-rata hasil tinggi tanaman $5 \mathrm{MST}$ dan 6 MST, jumlah daun 5 MST, biomassa 5 MST dan 6 MST dan jumlah umbi per rumpun serta bobot umbi kering per rumpun. Mikroba Pelarut Fosfat memberikan pengaruh mandiri terhadap rata-rata hasil tinggi tanaman $5 \mathrm{MST}$ dan $6 \mathrm{MST}$, bobot umbi segar dan bobot umbi kering per rumpun. Terdapat hubungan korelasi yang nyata antara tinggi tanaman
5 MST dan 6 MST serta jumlah daun 5 MST terhadap rata-rata hasil bobot umbi kering per petak tanaman bawang merah.

\section{DAFTAR PUSTAKA}

Asandhi, AA, Nurtika, N \& Sumarni, N 2005, 'Optimasi pupuk dalam usahatani LEISA bawang merah di dataran rendah', J.Hort., vol. 15, no. 3, hlm. 199-207

Elfiati, D. 2005. Peranan Mikroba Pelarut $P$ Terhadap Pertumbuhan Tanaman. Jurnal USU. http://library.usu.ac.id/. 27 Juli 2019 pk. 21.30 WIB

Ginting, R. C. B. R. Saraswati. dan E. Husen. 2006. Pupuk Organik dan PupukHayati. Balai Besar Litbang Sumber Daya Lahan Pertanian. Bogor.

Gunadi, N 2009, 'Kalium sulfat dan kalium klorida sebagai sumber pupuk kalium pada tanaman bawang merah', J.Hort., 9 (2) : 174-85.

Handayani, S. 2001. Cara Bertanam Bawang Sumenep. Trubus No. 46 Tahun ke-4. Penebar Swadaya. Jakarta.

Napitupulu, D \& Winarto, L 2010, 'Pengaruh pemberian pupuk $\mathrm{N}$ dan $\mathrm{K}$ terhadap pertumbuhan dan produksi bawang merah', J.Hort., vol. 20, no. 1, hlm. 27-35

Richardson, A.E., P.A. Hadodas, J.E. Hayes, C.P. O'Hara, and R.J. Simson. 2001. Utilization of Phosphorus by Pasture Plants Supplied With Myo-inositol Hexaphosphate is Enhanced by The Presence of Soil Microorganism. PlantSoil 229 : p. 47-56. 
Rosmarkam, H.A. dan N.W. Yuwono. 2002. Ilmu Kesuburan Tanah. Penerbit Kanisius, Jakarta.

Santosa, E. 2007. Mikroba Pelarut Fosfat. Metode Analisis Biologi Tanah. Balai Besar Sumberdaya Lahan Pertanian. Badan Penelitian dan Pengembangan Pertanian Departemen Pertanian, Bogor. Hal. 55-56.

Sanchez, P. 1992. Sifat dan Pengelolaan tanah Tropika. ITB Bandung

Suriani N. 2011. Bawang bawa untung budidaya bawang merah dan bawang putih. Cahaya Atma Pustaka. Yogyakarta.

Suwandi \& Rosliani, R 2004, 'Pengaruh kompos, pupuk nitrogen, dan kalium pada cabai yang ditanam tumpang gilir dengan bawang merah', J.Hort., vol. 14, no. 1, hlm. 41-8

Toto Warsa dan Cucu, S.A., 1982. Teknik Perancangan Percobaan (Rancangandan Analisis). Fakultas Pertanian UNPAD, Bandung.

Wahida, A., A. Fahmi, dan A. Jumberi. 2007. Pengaruh Pemberian Fosfat Alam Asal Maroko terhadap Pertumbuhan Padi di Lahan Sulfat Masam. J. Tanah Tropik, 12(2): 85-91 